\title{
Correspondence
}

\section{Potential Use of Secoyohimban Derivatives isolated from Water hyacinth as inhibitors of the COVID-19 Virus}

\author{
Hany A. El-Shemy ${ }^{1 !}$, Emad A. Shalaby $^{1}$ and David A. Lightfoot ${ }^{2}$ \\ 1) Department of Biochemistry, Faculty of Agriculture, Cairo University, 12613 Giza, \\ Egypt. \\ 2) Genomics Facility, SIUC, Carbondale, IL, USA.
}

! Correspondence Author: Hany A. El-Shemy, Dept. of Biochemistry, Faculty of

Agriculture, Cairo University, 12613 Giza, Egypt.

E-mail address: helshemy@yahoo.com

COVID-19 is an abbreviation for Coronavirus disease 2019 referring to an infectious disease caused by severe acute respiratory syndrome coronavirus 2 (SARS-CoV-2). The disease was first identified in 2019 in Wuhan, Central China, and has since spread globally, resulting in the 2019-20 coronavirus pandemic (With more than 300 thousand infections by early 2020) ${ }^{1}$.

During 2005, chloroquine was discovered as potent inhibitor of SARS coronavirus infection, the action of chloroquine is preventing the spread of SARS CoV in cell culture ${ }^{2}$. This effect was due to prophylactic and therapeutic advantages. In addition to the well-known functions of chloroquine, such as elevations of endosomal $\mathrm{pH}$, the drug appears to interfere with terminal glycosylation of the cellular receptor, angiotensin converting enzyme (ACE- 2$)^{2}$.

Currently, different countries and agencies talk about the potential use of chloroquine as potent inhibitor of Covid-19 virus (the virus shares substantial similarity with SARS-CoV) ${ }^{3}$. Some of pharmaceutical companies announced initial positive feedback for the effect of this drug as inhibitor of COVID-19.

This activity may be due to the unique chemical structure of chloroquine which has two benzene rings, with five double bonds and several electronegative atoms (Figure 1). In this journal, we published various articles during 2010 and $2014^{4,5}$ for the effect of isolated compounds from athe Amazonian invasive species water hyacinth (Eichhornia crassipes (Mart.) Solms) from River Nile in Egypt inhibiting different bacteria, yeast, fungi and human cancer. They had high activity when compared with antibiotics and other standards (IPR was registered for all compounds in the Academy of Scientific Research, Patent office, Egypt).

Why we expected the potential use of Secoyohimban alkaloids and derivatives as inhibitors for COVID-19?

a) There is great similarity in the chemical structure between the chloroquine and one compound isolated from water hyacinth (Secoyohimban derivatives) as shown in 
Figure (1). Furthermore, The Figure (2) illustrates the resonance phenomena happened in both compounds and gave the similarity picture for the main part of these compounds which emphasize the ability of Secoyohimban as an anti COVID-19.

b) There is great similarity in the biological activities and active groups between the both compounds as shown in Table 1 . This similarity may be given high potential for use the natural compounds from water hyacinth as antiviral activities via its affect in elevations of endosomal $\mathrm{pH}$.

c) Possibly these natural compounds acts as competitive inhibitors of the virus during its receptor (S protein-human ACE2 interface) ${ }^{3}$ or interaction directly with S-Protein (in the COVID 19 structure) and this may be due to the suggested interaction between the active groups in the chemical structure of this compound and amino acid chains in the S-protein or in the ACE2 receptor ${ }^{3}$ as shown in Figures 3.

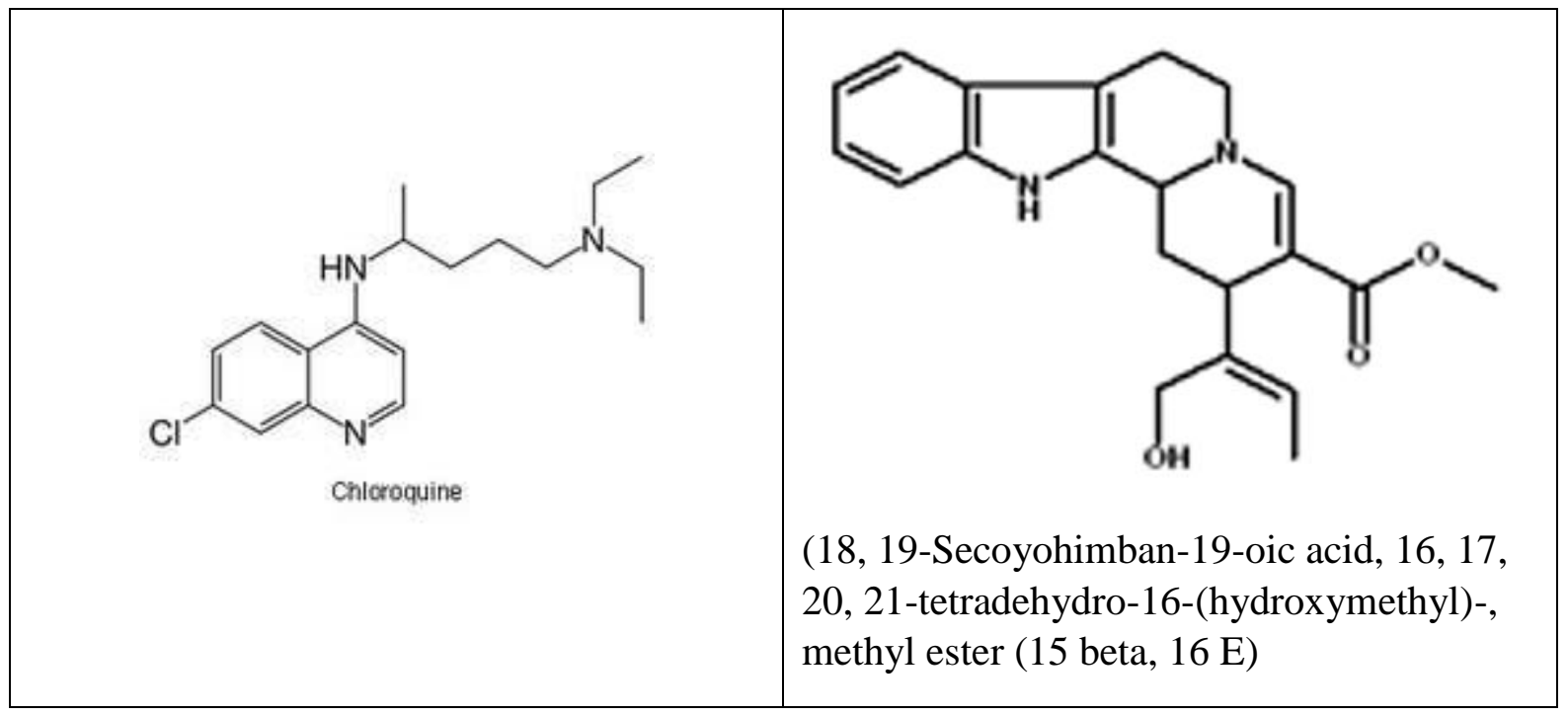

Figure 1: The chemical structure of Chloroquine and Secoyohimban Derivatives 
Table 1: The chemical properties of Chloroquine and Secoyohimban Derivatives

\begin{tabular}{|c|c|c|}
\hline \multirow[b]{2}{*}{ Properties } & \multicolumn{2}{|c|}{ Compounds name } \\
\hline & Chloroquine & $\begin{array}{c}\text { 18, 19-Secoyohimban-19-oic acid, 16, } \\
\text { 17, 20, 21-tetradehydro-16- } \\
\text { (hydroxymethyl)-, methyl ester (15 } \\
\text { beta, 16 E) }\end{array}$ \\
\hline The chemical formula & $\mathrm{C}_{18} \mathrm{H}_{26} \mathrm{Cl} \mathrm{N} \mathrm{N}_{3}$ & $\mathrm{C}_{21} \mathrm{H}_{23} \mathrm{~N}_{2} \mathrm{O}_{3}$ \\
\hline M.Wt & $320 \mathrm{Da}$ & $352 \mathrm{Da}$ \\
\hline Chemical nature & Alkaloid & Alkaloid \\
\hline Resonance groups & $\begin{array}{l}\text { Benzene ring }- \text { double } \\
\text { bonds } \\
\text { Electron-rich molecules } \\
(\mathrm{N}, \mathrm{Cl})\end{array}$ & Benzene ring - double bonds \\
\hline $\begin{array}{l}\text { Biological activities } \\
\text { (according to what } \\
\text { mentioned } \\
\text { published articles) }\end{array}$ & $\begin{array}{l}\text { - Antimalarial } \\
\text {-Anti-inflammatory- } \\
\text { antioxidant activities }\end{array}$ & $\begin{array}{l}\text { - Antibiotics active against some } \\
\text { pathogenic strains of bacteria, fungi and } \\
\text { algae. } \\
\text { - Anticancer and antioxidant activities }\end{array}$ \\
\hline
\end{tabular}

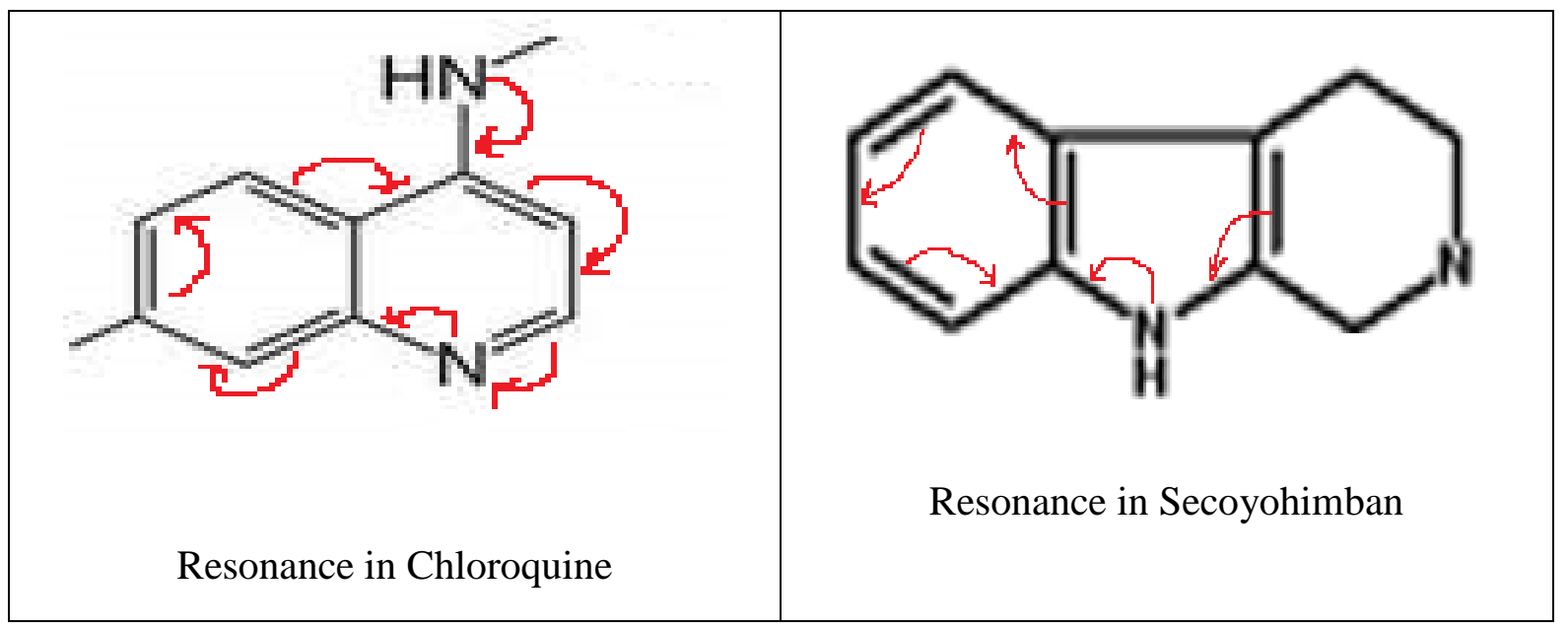

Figure 2: The Resonance Phenomena in main part of Chloroquine and Secoyohimban Derivatives 
Our findings indicate that natural compound isolated from water hyacinth may be used as potent inhibitor of COVID-19 virus and we will start the extraction and separation of this active ingredient with high amount for testing it as anti-COVID-19 in addition to use docking study as a strategy to identify the interaction between the active ingredient and target/ (receptor), in cooperation with the National Research Centre in Egypt.

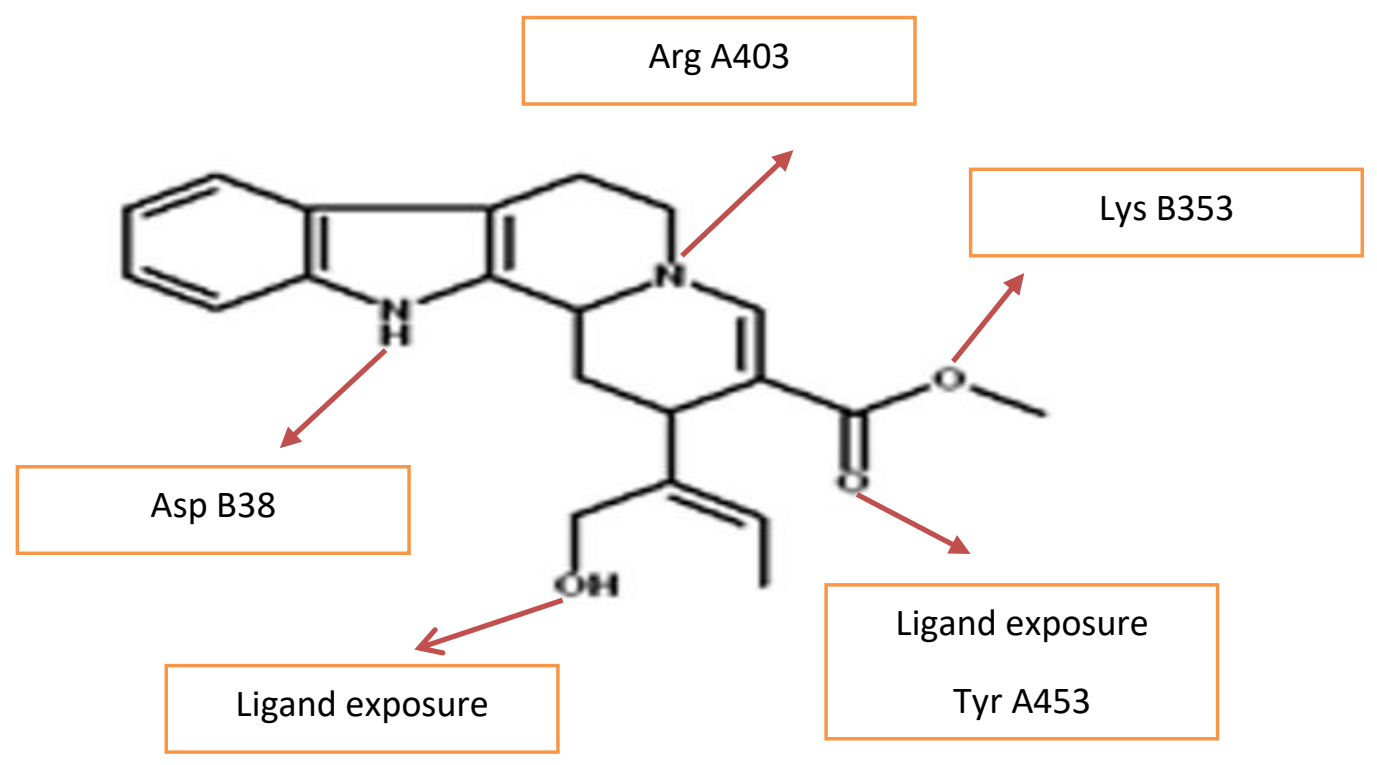

Figure 3: Suggested Secoyohimban S-protein or ACE2 receptor interaction diagram. Residues with (A) correspond to the S-protein, while those with (B) correspond with the ACE2 receptor ${ }^{3}$.

Once confirmed the usage of active ingredients from water hyacinth which was grown in Nile River starting from Ethiopia to Egypt via Sudan, this might bring all back to solve water issues because they will switching the dialogue to be discussed about the economic revenues after using the active ingredients from water hyacinth.

In conclusion, COVID-19 might solve the problems between nations due to scientific outcomes for treatments from water hyacinth and positive economic feedbacks.

\section{References}

1. National Health Commission. 7 February 2020. Archived from the original on 28 February 2020. Retrieved 9 February 2020.

2. Vincent, MJ., Bergeron, E., Benjannet, S., Erickson, BR., Rollin, BE., Ksiazek, TG., Seidah, NG and Nichol, ST. 2005. Chloroquine is a potent inhibitor of SARS coronavirus infection and Spread, Virology Journal, 2 (69): 1-10.

3. Smith, Micholas; Smith, Jeremy C. 2020. Repurposing Therapeutics for COVID19:Supercomputer-Based Docking to the SARS-CoV-2 Viral Spike Protein and Viral Spike Protein-Human ACE2 Interface. ChemRxiv. Preprint. https://doi.org/10.26434/chemrxiv.11871402.v3 
4. Shanab SMM, Shalaby EA, Lightfoot DA, El-Shemy HA. 2010. Allelopathic Effects of Water Hyacinth [Eichhornia crassipes]. PLoS ONE 5(10): e13200. doi:10.1371/journal.pone.0013200.

5. Aboul-Enein, AM., Shanab, SMM., Shalaby, EA., Zahran, MM., Lightfoot, DA., El-Shemy. HA. 2014. Cytotoxic and antioxidant properties of active principals isolated from water hyacinth against four cancer cells lines. BMC Complementary and Alternative Medicine 14:397. 